\title{
PERSEPSI GURU TERHADAP PENYELENGGARAAN PENDIDIKAN INKLUSIF DI BANJARMASIN
}

\author{
Mirnawati \\ Universitas Lambung Mangkurat \\ mirnawati.plb@ulm.ac.id \\ Ali Rachman \\ Universitas Lambung Mangkurat \\ andesmida@gmail.com \\ Algia Warni \\ Universitas Lambung Mangkurat \\ algiawarni@gmail.com
}

\begin{abstract}
Abstrak
Permasalahan pada penelitian ini dilatar belakangi oleh adanya kesulitan guru dalam mengimplementasikan penyelenggaraan Pendidikan Inklusif, yang baru saja diselenggarakan semenjak tahun 2017 di SDN Sungai Andai 3 Banjarmasin. Penelitian ini bertujuan untuk mendeskripsikan persepsi guru terhadap penyelenggaraan Pendidikan Inklusif di SDN Sungai Andai 3 Banjarmasin, yang meliputi 3 aspek sesuai dengan pertanyaan penelitian, antara lain: Persepsi guru terhadap konsep dasar ABK, persepsi guru terhadap pendidikan ABK serta persepsi guru terhadap sarana dan prasarana. Penelitian ini menggunakan jenis penelitian kualitatif dengan pendekatan deskriptif.Informasi mengenai persepsi pada tiap responden diungkap melalui angket dengan 22 pernyataan dan wawancara mendalam sebagai teknik pengumpukan data serta dokumentasi.Teknik analisis data dalam penelitian ini yaitu reduksi data, penyajian data, serta penarikan kesimpulan.Guru yang dimaksud dalam penelitian ini adalah guru kelas dan guru mata pelajaran, serta GPK yang bukan berlatar belakang PLB. Penelitian ini dilakukan pada 23 responden yang mengajar di SDN Sungai Andai 3 Banjarmasin. Hasil penelitian yang berkaitan dengan tujuan penelitian bahwa persepsi guru terhadap konsep dasar ABK dapat dikatakan "Baik". Sedangkan Persepsi Guru terhadap Pendidikan ABK dan sarana prasarana dapat dikatakan "Cukup". Sehingga disimpulkan bahwa persepsi guru terhadap penyelenggaraan pendidikan inklusif di SDN Sungai Andai 3 Banjarmasin adalah "Baik".
\end{abstract}

Kata Kunci: persepsi, guru, pendidikan inklusif.

\section{PENDAHULUAN}

Pada dasarnya pendidikan inklusif merupakan sebuah konsep yang muncul untuk memberikan solusi terhadap persoalan dalam pendidikan, namun masalah yang terjadi dalam upaya penyelenggaraannya selalu bermunculan. Salah satunya adalah masalah tenaga pendidik, yaitu guru kelas, guru mata pelajaran dan guru pembimbing khusus (GPK) yang bukan berlatar belakang Pendidikan Khusus. 
Oleh sebab itu, tenaga pendidik tersebut diasumsikan mengalami kesulitan dalam penerapan di lapangan, karena pengetahuan maupun kemampuannya sebatas di bidang umum yang mereka kuasai saja atau bahkan belum pernah mendapatkan materi mengenai Pendidikan Inklusif maupun materi mengenai Anak Berkebutuhan Khusus yang dapat menunjang kerja profesi mereka. Sehingga syarat keilmuaan pengetahuan guru regular sebenarnya belum memadai untuk dapat menyelesaikan masalah-masalah yang mungkin muncul ketika sekolah telah berupaya menyelenggarakan pendidikan inklusif.

Secara otomatis mereka akan memerlukan bimbingan atau pengetahuan yang lebih dalam pelayanan pendidikan pada bidang kekhususan yang akan berhubungan dengan pendidikan inklusif. Adanya persepsi yang beragam seringkali membuat guru merasa kebingungan, dari persepsi positif hingga negatif yang muncul di kalangan tenaga kependidikan. Hal teresebut dapat berpengaruh buruk pada sikap serta tingkah laku dalam menjalankan profesinya sebagai seorang guru. Oleh sebab itu, untuk dapat mengubah tingkah laku seseorang maka harus dimulai dari mengubah persepsinya atau pemikirannya tentang suatu hal terlebih dulu. Meskipun penyelenggaraan pendidikan inklusif tersebut memiliki legalitas dan mendapat dukungan sepenuhnya dari pemerintah, namun masih terdapat keragaman persepsi yang menunjukkan pandangan negatif terhadap penyelenggaraan pendidikan inklusif. (Kustawan, 2012:8).

Persepsi guru dalam penyelenggarakan pendidikan inklusif pada penelitian ini yaitu pendapat guru tentangsetuju atau tidaknya mengenaipenyelenggaraan pendidikan inklusif yang akan meliputi; konsep dasar ABK, pendidikan ABK serta sarana dan prasarana dalam penyelenggaraan pendidikan inklusif di sekolah yang mereka jadikan sebagai tempat profesinya. SDN Sungai Andai 3 Banjarmasin merupakan sekolah yang berada di kota Banjarmasin Provinsi Kalimantan Selatan, Kecamatan Banjarmasin Utara, Kelurahan Sungai Andai yang berdiri sejak tahun 2012.

Sekolah tersebut baru berjalan 6 tahun (artinya di tahun ini baru saja ada siswa yang lulus dan menjadi alumni). SDN Sungai Andai 3 Banjarmasin merupakan salah satu sekolah yang ikut serta dalam penyelenggaraan pendidikan inklusif, dengan menerima ABK. Namun masih terbilang baru karena berjalan kurang lebih sekitar 1 tahun. Sekolah tersebut memberanikan diri untuk inklusif meskipun terbilang masih baru dan terus meningkatkan pembangunannya.

Berdasarkan observasi terlihat berbagai macam 
tanggapan yang muncul di lapangan terkait dengan penyelenggaraan pendidikan inklusif. Berbagai respon yang tidak selaras menimbulkan kebingungan dan masalah dalam penerapan penyelenggaraan pendidikan inklusif di sekolah tersebut.Akhirnya menjadi suatu hal yang menarik untuk dilakukan penelitian, untuk mendeskripsikan "Persepsi Guru terhadap Penyelenggaraan Pendidikan Inklusif di SDN Sungai Andai 3 Banjarmasin".

\section{METODE}

Penelitian ini menggunakan pendekatan penelitian kualitatif dan termasuk jenis penelitian deskriptif yang dijabarkan untuk menggambarkan keadaan yang muncul sesuai dengan apa adanya. Jenis penelitian ini dipilih karena peneliti berusaha untuk mendeskripsikan tentang persepsi guru terhadap penyelenggaraan pendidikan inklusif di SDN Sungai Andai 3 Banjarmasin.Tempat pelaksanaan pada penelitian ini adalah SDN Sungai Andai 3 Banjarmasin yang beralamat di Jalan Padat Karya Komplek Kayu Bulan Blok C-5 RT.62 RW.03 Banjarmasin Utara Kelurahan Sungai Andai Provinsi Kalimantan Selatan.Subjek dalam penelitian ini adalah Guru.

Guru yang dimaksud yaitu Guru Kelas, Guru Mata Pelajaran dan GPK yang bukan berlatar belakang Pendidikan Khusus. Teknik pengumpulan data yang digunakan adalah angket, wawancara, dan dokumentasi. Teknik analisis data dalam penelitian ini yaitu reduksi data, penyajian data, serta penarikan kesimpulan, Keabsahan data yang digunakan meliputi; perpanjangan pengamatan, ketekunan pengamatan, dan member check.

\section{PEMBAHASAN}

\begin{tabular}{|c|c|c|c|c|c|}
\hline \multirow{2}{*}{ Variabel } & \multirow[t]{2}{*}{ Indikator } & \multicolumn{4}{|c|}{ Persentase } \\
\hline & & SS & $\mathrm{S}$ & TS & STS \\
\hline \multirow[t]{3}{*}{$\begin{array}{l}\text { Perspsi } \\
\text { guru }\end{array}$} & $\begin{array}{l}\text { Persepsi } \\
\text { Guru } \\
\text { terhadap } \\
\text { Konsep } \\
\text { Dasar ABK }\end{array}$ & $\begin{array}{c}66,5 \\
\%\end{array}$ & $\begin{array}{c}26,7 \\
\%\end{array}$ & $\begin{array}{l}6,8 \\
\%\end{array}$ & $0 \%$ \\
\hline & $\begin{array}{l}\text { Persepsi } \\
\text { Guru } \\
\text { terhadap } \\
\text { Pendidikan } \\
\text { ABK }\end{array}$ & $\begin{array}{c}39,5 \\
\%\end{array}$ & $\begin{array}{c}53,3 \\
\%\end{array}$ & $\begin{array}{c}7,2 \\
\%\end{array}$ & $0 \%$ \\
\hline & $\begin{array}{l}\text { Persepsi } \\
\text { Guru } \\
\text { terhadap } \\
\text { Sarana dan } \\
\text { Prasarana }\end{array}$ & $\begin{array}{c}26,1 \\
\%\end{array}$ & $\begin{array}{c}50,7 \\
\%\end{array}$ & $\begin{array}{l}18, \\
8 \%\end{array}$ & $\begin{array}{l}4,4 \\
\%\end{array}$ \\
\hline
\end{tabular}

\section{Persepsi Guru terhadap Konsep Dasar ABK}

Pada kenyataannya guru yang ada di SDN Sungai Andai 3 Banjarmasin, belum seluruhnya mengetahui klasifikasi ABK. Meskipun sebagian besar menunjukkan indikasi bahwa mereka mengetahui ABK, namun ternyata belum mengenalnya lebih dalam baik itu latar belakang dan kebutuhan masing-masing peserta didiknya. Mereka menerima peserta didik yang berkebutuhan khusus 
didalam kelas namun belum memahami apa karakteristik $\mathrm{ABK}$ tersebut.

Padahal menurut Kustawan (2012), setiap guru harus memiliki kemampuan untuk mengidentifikasi peserta didik maupun calon peserta didik untuk mengetahui semua peserta didik dan lebih fokus lagi mengetahui ada tidaknya peserta didik berkebutuhan khusus yang perlu mendapatkan layanan pendidikan yang sesuai dengan kebutuhannya. Dalam hal inilah penting bagi seorang guru untuk memahami keberagaman karakteristik peserta didiknya, sehingga perencanaan maupun kegiatan pembelajaran dapat dilakukan berdasarkan kebutuhan yang dimiliki oleh peserta didik. Oleh sebab itu, guru perlu menanamkan persepsi yang baik dan memandang keberagaman karakteristik ABK bahwa segala perbedaan bukanlah masalah.Sebab pendidikan inklusif adalah pendidikan untuk semua. Artinya guru-lah yang harus berupaya mencari solusi untuk memenuhi kebutuhan pendidikan peserta didiknya yang beragam dengan menggali informasi lebih dalam dan menjalin kerja-sama yang baik dengan semua.

\section{Persepsi Guru terhadap Pendidikan ABK}

Perencanaan pembelajaran tentang pelaksanaan identifikasi dan asesmen ternyata telah dilakukan dengan baik di SDN Sungai Andai 3 Banjarmasin. Namun hal tersebut hanya pernah dilaksanakan oleh GPK yang bukan berlatar belakang PLB.Sementara guru kelas maupun guru mata pelajaran tidak ikut serta didalamnya, sehingga mereka kurang mengetahui dengan baik prosesnya. Hal tersebut membuat guru kelas maupun guru mata pelajaran kesulitan dalam memberikan layanan pendidikan yang sesuai dengan kebutuhan ABK disekolah tersebut. Pelaksanaan pemberian pendidikan ABK di SDN Sungai Andai 3 Banjarmasin menggunakan kurikulum KTSP namun belum dapat mengakomodasi atau menyesuaikan anak berkebutuhan khusus. Sehingga dalam penerapan kurikulum untuk anak berkebutuhan khusus sama dengan peserta didik regular (pukul rata). Sedangkan program pembelajaran individual (PPI) baru saja terencana dan dilaksanakan oleh guru pendidikan khusus. Proses pembelajaran belum dapat disesuaikan dengan kebutuhan ABK yang ada disekolah tersebut, selain itu penilaian juga menggunakan KKM yang sama dengan anak pada umumnya.

Padahal menurut Kustawan (2013), Ruang lingkup kurikulum penyelenggara inklusif adalah kurikulum sekolah umum, namun dalam hal-hal tertentu dilakukan penyesuaian dan modifikasi sesuai dengan hambatan dan kebutuhan anak berkebutuhan khusus.Selain itu penilaian terhadap $A B K$ diperlukan 
adanya penyesuaian.Oleh sebab itu, diperlukan informasi dan arahan guna memperbaiki persepsi guru mengenai pendidikan ABK agar tidak selalu menyamaratakan dengan anak pada umumnya. Secara garis besar terkait dengan permasalahan diatas, maka kolaborasi antara guru pendidikan khusus sangat diperlukan terutama dalam hal perencanaan pembelajaran yang meliputi: tindak lanjut dari hasil identifikasi dan asesmen, program pembelajaran individual, proses pembelajaran dan KKM yang disesuaikan, serta penggunaan kurikulum yang fleksibel dan dapat mengakomodasi ABK.

\section{Persepsi Guru terhadap Sarana dan Prasarana}

Pada kenyataannya di SDN Sungai Andai 3 Banjarmasin sistem dukung sarana dan prasarana belum memadai.Hal tersebut dibuktikan dengan belum adanya kelas khusus dikarenakan finansial sekolah yang belum mencukupi.Beberapa media masih terbatas dan belum bisa digunakan untuk $\mathrm{ABK}$ yang memiliki hambatan beragam karakteristik atau belum sesuai dengan kebutuhannya. Aksesibilitas fisik yang dimiliki oleh sekolah tersebut antara lain: halaman sekolah, ruang kelas 1-6, dan toilet. Belum tersedianya tanda-tanda khusus sekolah untuk ABK.Sedangkan aksesibilitas non fisik, baru saja tesedia guru pendidikan khusus sebagai sumber

daya manusia yang dianggap memiliki kompetensi dalam mengajari anak berkebutuhan khusus.

Sarana dan prasarana merupakan faktor yang penting dalam mendukung keberhasilan terselenggaranya pendidikan yang inklusif. Menurut Wahyuningrum 2004 dalam (Ilahi: 2013) menyatakan sarana dan prasarana adalah segala sesuatu yang dapat mempermudah pelaksanaan suatu kegiatan. Apabila dikaitkan dengan konsep pendidikan inklusif, sarana dan prasarana sebagai penunjang pendidikan $\mathrm{ABK}$ antara lain: media pembelajaran, kelas khusus, aksesibilitas fisik maupun non fisik khususnya untuk peserta didik yang memiliki hambatan penglihatan, fisik, maupun gerak. Dalam kustawan 2012, UU No 4 tahun 1997 tentang penyandang cacat, aksesibilitas adalah kemudahan yang disediakan bagi penyandang cacat guna mewujudkan kesamaan dan kesempatan dalam segala aspek kehidupan dan penghidupan.

Oleh sebab itu, persepsi terhadap sarana dan prasarana perlu diluruskan. Hal tersebut memberikan manfaat tidak hanya untuk anak berkebutuhan khusus, namun bertujuan untuk memudahkan bagi semua orang antara lain: menunjang pelaksanaan pembelajaran, dan mewujudkan kemandirian. Selain itu, aksesibilitas fisik maupun non fisik yang menunjang akan memegang 
peranan strategis dalam memberikan Kustawan, Dedy. 2013. Model peluang dan kemudahan bagi ABK. Implementasi Pendidikan Inklusif Ramah Anak. Jakarta Timur: Luxima Metro Media.

\section{SIMPULAN}

Berdasarkan paparan hasil penelitian dan pembahasan maka dapat disimpulkan bahwa persepsi guru terhadap konsep dasar ABK dapat dikatakan "Baik". Sedangkan Persepsi Guru terhadap Pendidikan ABK dan sarana prasarana dapat dikatakan "Cukup".

\section{DAFTAR PUSTAKA}

Delphie, Bandi. 2009. Pembelajaran Anak Berkebutuhan Khusus Dalam Setting Pendidikan Inklusi.Sleman : Intan Sejati Klaten

Elisa Syafrida Dkk. 2014.Jurnal Psikologi Perkembangan. Sikap Guru Terhadap Pendidikan Inklusi ditinjau Dari Faktor Pembentuk Sikap, Di Akses Pada Tanggal 1 Januari 2018.

Ghony, M. Djunaidi \& Fauzan Almanshur. 2012. Metodologi Penelitian Kualitatif. Jogjakarta: ArRuzz Media.

Ilahi, Mohammad Takdir. 2013. Pendidikan Inklusif (Konsep dan Aplikasi). Jogjakarta: Ar-ruzz Media

Kustawan, Dedy. 2012. Pendidikan
Inklusif
Dan Upaya Implementasinya. Jakarta Timur: Luxima Metro Media.

Kustawan, Dedy. 2013. Manajemen Pendidikan Inklusif. Jakarta Timur: Luxima Metro Media.

Sugiyono. 2010. Metode Penelitian (Penelitian Kuantitatif, Kualitatif, $R$ $\mathcal{E} D$ ). Bandung: CV.Alfabeta.

Sugiyono. 2013. Metode Penelitian Pendidikan. Bandung: CV. Alfabeta.

Yuwono, Imam \& Utomo. 2015. Pendidikan Inklusif Paradigma Pendidikan Ramah Anak. Banjarmasin: Pustaka Banua 